\title{
GAMBARAN TINGKAT KEGAWAT DARURATAN PASIEN DI INSTALASI GAWAT DARURAT (IGD) RUMAH SAKIT BHAYANGKARA KOTA MANADO
}

\author{
Livnie Nansi Sahensolar ${ }^{1}$,Hendro Bidjuni ${ }^{2}$,Vandri Kallo ${ }^{3 *}$ \\ ${ }^{a}$ Livnie Nansi Sahensolar (Mahasiswi PSIK FK Unsrat, Indonesia) \\ ${ }^{b}$ Hendro Bidjuni (Dosen PSIK FK Unsrat, Indonesia) \\ ${ }^{c}$ Vandri Kallo (Dosen PSIK FK Unsrat, Indonesia) \\ *Email :nsahensolar11@gmail.com
}

\begin{abstract}
Background in this research, namely a State of emergency is situation that requires the handling or action immediately to eliminate the treat life of the victim. The research of aim is to know the Description of the level of emergency patients in the Emergency Room (ER) Hospital Bhayangkara Manado City. The Method is using descriptive research. Sample in this research amounted to 100 respondents obtained through medical record with the research instrument used is in the form of observation sheet which consists of the priority handling of patients is to determine priority I and Priority II. The results of the research, the characteristics based on the age of the response and the most on the age of The Elderly the Beginning of 46-55 years with a total of 24 respondents (24\%), characteristics based on the gender of largest in the male gender with a total of 54 respondents (54\%), characteristics based on the medical diagnosis most are on the medical diagnosis of Dyspepsia with the number 47 diagnosis (47\%), and based on Emergency patients are on Emergency priority of yellow with the amount of 62 respondents (62\%). Conclusion, Patients who come to the emergency room with emergency patients with Priority triage shows the most Priority Triage yellow.
\end{abstract}

Keywords : Dyspepsia; Emergency Room; Priority of the Patient; Rate of Emergency Patients; Triage

Abstrak: Latar Belakang penelitian yaitu Keadaan gawat darurat merupakan keadaan yang memerlukan penanganan atau tindakan segera untuk menghilangkan ancaman nyawa korban. Tujuan penelitian untuk mengetahui Gambaran tingkat kegawat daruratan pasien di Instalasi Gawat Darurat (IGD) Rumah Sakit Bhayangkara Kota Manado. Metode Penelitian ini menggunakan penelitian deskriptif. Sampel, pada penelitian ini berjumlah 100 responden yang diperoleh melalui rekam medis dengan instrument penelitian yang digunakan yaitu dalam bentuk lembar oservasi yang terdiri dari prioritas penanganan pasien yaitu untuk menentukan prioritas I dan Prioritas II. Hasil penelitian, karakteristik berdasarkan umur respon dan terbanyak pada umur Masa Lansia Awal 46-55 tahun dengan jumlah 24 responden (24\%), karakteristik berdasarkan jenis kelamin terbanyak pada jenis kelamin laki-laki dengan jumlah 54 responden $(54 \%)$, karakteristik berdasarkan diagnose medis terbanyak berada pada diagnose medis Dysepsia dengan jumlah 47 diagnose (47\%), dan berdasarkan kegawat daruratan pasien terbanyak berada pada kegawat daruratan prioritas kuning dengan jumlah 62 responden $(62 \%)$. Kesimpulan, Pasien yang datang ke Instalasi gawat darurat dengan kegawat daruratan pasien dengan Prioritas triase menunjukan sebagian besar Prioritas Triase kuning.

Kata Kunci : Dispepsia; Instalasi Gawat Darurat; Prioritas Pasien; Tingkat Kegawat daruratan Pasien; Triase 


\section{PENDAHULUAN}

Keadaan gawat darurat merupakan keadaan yang memerlukan penanganan atau tindakan segara untuk menghilangkan ancaman nyawa korban. Dalam tubuh manusia terdapat berbagai organ dan semua itu terbentuk dari sel-sel, sel dalamtubuh akan hidup apabila pasokan oksigen mencukupi, dan bisa terjadi kematian sel tubuh apabila tidak mendapat pasokan oksigen. Kematian di bagi menjadi dua macam yaitu mati bologis dan mati klinis, seseorang dikatakan mati klinis jika mengalami henti nafas dan henti jantung, waktu 6-8 menit setelah terhentinya pernafasan dan henti jantung sedangkan mati biologis adalah mulai terjadinya kerusakan sel-sel otak dan waktunya dimulai 6 sampai dengan 8 menit setelah berhentinya sistem pernafasan dan sirkulasi (Musliha, 2010 dalam Aulia, 2019). Filosofi penanganan pasien gawat darurat adalah Time Saving it's Live Saving. Artinya adalah seluruh tindakan yang dilakukan di ruang gawat darurat haruslah benar-benar efektif dan efisien, karena pasien akan kehilangan nyawa hanya dalah hitungan menit saja. Berhenti nafas 2-3 menit pada manusia dapat menyebabkan kematian yang fatal (Surtiningsih dkk. 2016).

Menurut Hartati \& Halimuddin (2017), indikator keberhasilan dalam penanganan medik pasien gawat darurat adalah kecepatan dalam memberikan pertolongan kepada pasien gawat darurat. Keberhasilan waktu tanggap atau yang biasa di sebut dengan response time sangat bergantung pada kecepatan pemberian pertolongan serta kualitas yang di berikan untuk menyelamatkan nyawa atau mencegah cacat sejak kejadian di tempat, dalam perjalanan hingga pertolongan rumah sakit. Instalasi Gawat Darurat dikelola untuk menangani pasien gawat darurat mengancam jiwa yang melibatkan tenaga profesional terlatih serta didukung dengan peralatan khusus, sehingga perawat dalam memberikan pelayanan pasien secara cepat dan tepat. Ketepatan pelayanan di Instalasi Gawat Darurat harus didukung dengan pelaksanaan triage yang benar (Susanti, 2018).

Triage merupakan suatu kegiatan memilih dan memilah pasien yang akanmasuk ke IGD, dari proses memilih dan memilah pasien yang masuk ke IGD akan dikategorikan kedalam pasien true emergency dan false emergency (Conrad, 2012 dalam Susanti, 2018). Diperlukan kesiapan dan peran tenaga kesehatan termasuk perawat IGD dalam penerapan konsep triage untuk menangani kondisi kegawat daruratan. Pada kegiatan triage, perawat bertanggungjawab penuh dalam pengambilan keputusan segera (decision making), melakukan pengkajian resiko, pengkajian sosial, diagnosis, dan menentukan prioritas serta merencanakan tindakan berdasarkan tingkat urgency pasien (Susanti, 2018).

Berdasarkan beberapa hasil penelitian masih tedapat keterlambatan waktu tanggap di beberapa RS. Penelitian yang dilakukan oleh Maatilu (2014) tentang faktor-faktor yang berhubungan dengan response time pada penanganan pasien gawat darurat di IGD RSUP PROF. Dr. R. D. Kandou Manado bahwa hasil penelitian didapatkan response time perawat dalam penanganan kasus gawat darurat rata-rata lambat (> 5 menit). Sedangkan penelitian yang dilakukan oleh Noor (2009) tentang faktor-faktor yang mempengaruhi response time pada penanganan pasien IGD RSUP persahabatan bahwa hasil penelitiannya didapatkan waktu tanggap 7.45 menit. Selanjutnya penelitian yang dilakukan oleh Achmad (2012) tentang faktor-faktor yang berhubungan dengan lama waktu tanggap perawat pada penanganan asma di IGD RSUD Panembahan Senopati Bantul bahwa hasil penelitian menunjukkan bahwa perawat mempunyai waktu tanggap cepat ( $<5$ menit) sebanyak 12 orang (60\%) dan waktu 
tanggap lambat ( $>5$ menit) sebanyak 8 orang (40\%).

Hasil studi pendahuluan yang dilakukan bulan Maret Tahun 2021 didapatkan data jumlah kunjungan pasien di IGD Rumah Sakit Bhayangkara dengan rata-rata kunjungan pasien perhari pada tahun 2020 mencapai 16.435 pasien. Dari hasil observasi yang dilakukan di IGD Rumah Sakit Bhayangkara diperoleh rata-rata kegawatan daruratan pasien berfariasi. Data laporan bulanan Februari tahun 2021 sebanyak 100 pasien yang masuk ke IGD dengan diagnose penyakit yang berbeda dengan angka kematian pasien yaitu bulan Januri sebanyak 4 pasien, bulan Februari sebanyak 7 pasien. Dari data tersebut terdapat kecenderungan peningkatan kasus kematian pasien di IGD tahun 2021 masih terjadi. Pasien yang masuk lewat IGD dengan kegawatan darurat ataupun tidak, semua dikaji oleh perawat berdasarkan prioritas pasien, (Profil RS, 2021).

\section{METODE}

Penelitian ini menggunakan penelitian deskriptif dengan pendekatan cross sectional. Populasi pada penelitian ini kepada perawat di UGD IGD Rumah Sakit Bhayangkara Manado yang berjumlah 100 responden. Pengambilan sampel pada penelitian ini menggunakan total sampling. Instrumen dalam pengumpulan data dan informasi pada responden, peneliti menggunakan pengumpulan data dalam bentuk Lembar Observasi yaitu diberikan centang Prioritas 1 di berikan nilai 3 (Merah) korban membutuhkan stabilisasi segera atau dalam keadaan kritis, Prioritas II dengan diberi nilai 2 (kuning) korban membutuhkan pertolongan dan pengawasan ketat perawatan dan dapat ditunda sementara selama 10 menit, dan Priotitas III di berikan nilai 1 korban masih mampu berjalan pemberian perawatan dapat ditunda 60 menit. Pengolahan data yang diperoleh dari hasil penelitian ini diolah secara manual dan dianalisis secara statistic melalui komputerisasi dengan beberapa tahap yaitu editing, coding, dan cleaning yang dilakukan terhadap variable penelitian untuk meneliti tampilan distribusi frekuensi dan presentase dari tiap-tiap variable dengan menggunakan Chi-Square.

Dalam melakukan penelitian, peneliti menggunakan etika penelitian yang terdiri dari Informed consent, Anonymity (tanpa nama), dan Confidentially. Analisa data dilakukan terhadap variabel penelitian untuk meneliti tampilan distribusi frekuensi dan presentase dari tiap-tiap variable.

\section{HASIL PENELITIAN}

Tabel 1. Distribusi Frekuensi Responden Berdasarkan Karakteristik Responden

\begin{tabular}{cllcc}
\hline No & \multicolumn{1}{c}{ Variabel } & $\mathrm{f}$ & $\%$ \\
\hline 1. & Umur & & \\
& - & Balita 0-5 Tahun & 4 & 4.0 \\
& - & Kanak-Kanak 5- Tahun & 1 & 1.0 \\
& - & Remaja Awal 12-16 Tahun & 3 & 3.0 \\
& - & Remaja Akhir 17-25 Tahun & 17 & 17.0 \\
& - & Dewasa Awal 26-35 Tahun & 15 & 15.0 \\
& - & Dewasa Akhir 36-45 Tahun & 15 & 15.0 \\
& - & Lansia Awal 46-55 Tahun & 24 & 24.0 \\
& - & Lansia Akhir > 56 Tahun & & 21.0 \\
\hline 2. & Jenis Kelamin & 54 & 54.0 \\
& - & Laki-laki & 46 & 46.0 \\
\hline
\end{tabular}


Jurnal Keperawatan, Volume 9, No. 1, Februari 2021, (Hal. 1-8)

Berdasarkan tabel 1, distribusi responden berdasarkan umur responden, umur reponden terbanyak berada pada umur lansia awal 46-55 tahun sebanyak 24 responden $(24.0 \%)$. Menurt jenis kelamin responden, jenis kelamin terbanyak berada pada jenis kelamin laki-laki sebanyak 54 responden $(54 \%)$.

Tabel 2. Analisa Data Berdasarkan Diagnosa Medis

\begin{tabular}{lcc}
\hline DiagnosaMedis & n & \% \\
\hline Dysepsia & 47 & 47.0 \\
V.Laseratum & 13 & 13.0 \\
ISK & 3 & 3.0 \\
CKR & 5 & 5.0 \\
LER & 1 & 1.0 \\
Colik Abd & 4 & 4.0 \\
V.Ictum & 2 & 2.0 \\
Hematemesis & 2 & 2.0 \\
DiareAkut & 3 & 3.0 \\
Vertigo & 3 & 3.0 \\
Nefrolitiasis & 2 & 2.0 \\
Post. Nefrostomi & 1 & 1.0 \\
SNH & 1 & 1.0 \\
Fr. Clavicula & 1 & 1.0 \\
Lateri Pro Evaluasi & 1 & 1.0 \\
Susp. Fr. Humerus & 1 & 1.0 \\
App. Kronis & 1 & 1.0 \\
V. Morsum & 1 & 1.0 \\
Trauma Mata & 1 & 1.0 \\
CKD & 1 & 1.0 \\
DM T2 & 1 & 1.0 \\
Obs. Febris & 1 & 1.0 \\
Hipertensi & 1 & 2.0 \\
TB Paru & 1.0 \\
Inkontinensia Urine & 1 & 100 \\
\hline Jumlah & 1 & 1 \\
\hline
\end{tabular}

Berdasarkan hasil distribusi tabel 2 karakteristik berdasarkan diagnosa medis, diagnosa medis terbanyak berada pada diagnosa medis Dysepsia dengan jumlah 47 diagnosa $(47.0 \%)$.

Tabel 3. Berdasarkan Kegawat daruratan Pasien

\begin{tabular}{lcc}
\hline Kegawat daruratan/Prioritas & $\mathbf{n}$ & \% \\
\hline Kuning & 62 & 62.0 \\
Hijau & 38 & 38.0 \\
\hline Jumlah & $\mathbf{1 0 0}$ & $\mathbf{1 0 0}$ \\
\hline
\end{tabular}


Berdasarkan hasil distribusi tabel 3 karakteristik responden berdasarkan kegawat daruratan pasien, responden terbanyak berada pada kegawat daruratan prioritas kuning dengan jumlah 62

\section{PEMBAHASAN}

\section{Umur Responden}

Hasil penelitian menunjukan karakteristik responden berdasarkan umur responden, responden terbanyak berada pada umur Masa Lansia Awal 46 - 55 Tahun dengan jumlah 24 responden (24.0\%), sedangkan yang paling sedikit berada pada umur Masa Kanak-Kanak 5- Tahun dengan jumlah 1 responden (1.0\%). Penelitian sejalan dengan penelitian Ade, 2018 mengenai gambaran kunjungan pasien ke IGD berdasarkan Usia di rumah sakit Santa Elisabeth Medan tahun 2016 yang dilakukan terhadap 162 orang ditemukan bahwa pasien pada umur 56-65 tahun pasien yang datang ke IGD paling banyak berjumlah 31 orang $(19,1 \%)$ dan pada usia 6-11 tahun pasien yang paling sedikit yang berkunjung ke IGD berjumlah 8 orang $(4,9 \%)$.

Didominasi oleh rentang usia 46-55 tahun diperkirakan dipengaruhi oleh berbagai faktor seperti jenis penyakit seperti osteoporosis, penyakit janutung, masalah kehamilan, obesitas dll, tingkat pendidikan, nutrisi dll. Tingginya jumlah kasus pada rentang usia ini.

\section{Jenis Kelamin}

Hasil penelitian menunjukan karakteristik responden berdasarkan jenis kelamin responden, terbanyak berada pada jenis kelamin laki-laki dengan jumlah 54 responden $(54.0 \%)$, sedangkan yang paling sedikit berada pada jenis kelamin

perempuan dengan jumlah 46 responden (46.0 \%). Didominasi oleh laki-laki diperkirakan bergantung dari data masingmasing penyakit spesifik. Angka ini datang dari kasus trauma dan non trauma sehingga responden $(62.0 \%)$, sedangkan yang paling sedikit berada pada kegawat daruratan prioritas hijau dengan jumlah 38 responden $(38.0 \%)$.

dapat diperkirakan faktor-faktor yang memengaruhi perbedaan angka antara jenis kelamin pada masing-masing kasus pun berbeda (Takaendengan, 2016).

Penelitian ini sejalan dengan penelitian (Yudi, 2018) mengenai gambaran kunjungan pasien ke IGD berdasarkan Jenis kelamin di rumah sakit Santa Elisabeth Medan tahun 2016 yang dilakukan terhadap 162 responden ditemukan bahwa mayoritas pasien syangberkunjung berjenis kelamin laki-laki yaitu sebanyak 97 responden (59,9 $\%$ ) dan jenis kelamin perempuan yaitu sebanyak yaitu 65 responden $(40,1 \%)$.

\section{Diagnosa Medis}

Hasil penelitian menunjukan karakteristik berdasarkan diagnosa medis, diagnosa medis terbanyak berada pada diagnosa medis Dysepsia dengan jumlah 47diagnosa medis (47.0 \%). Asri, 2017 dalam Guyton (2015), bahwa sekresi lambung diatur oleh mekanisme saraf dan hormonal. Pengaturan hormon berlangsung melalui hormon gastrin. Hormon ini bekerja pada kelenjar gastric dan menyebakan aliran tambahan lambung yang sangat asam. Sekresi tersebut berlangsung selama beberapa jam. Hormon gastrin dipengaruhi oleh beberapa hal seperti adanya makanan dalam jumlah besar yang berada di lambung, juga zat sekretatogue seperti ektrak makan, hasil pencernaan protein, alkohol, dan kafein.

Hasil penelitian ini sejalan dengan penelitian Suryanti, 2019, tentang karakteristik penderita dispepsia pada kunjungan rawat jalan praktek pribadi dr. Suryanti periode bulan oktober-desember 2018, yang diperoleh hasil dispepsia merupakan salah satu masalah kesehatan yang sering ditemui pada praktek seharihari. Diperkirakan hampir 30\% kasus yang dijumpai pada praktek umum dan $60 \%$ pada praktek gastroenterology merupakan dyspepsia. 


\section{Kegawat Daruratan Pasien}

Hasil penelitian menunjukan karakteristik responden berdasarkan kegawat daruratan pasien, responden terbanyak berada pada kegawat daruratan prioritas kuning dengan jumlah 62 responden $(62.0 \%)$, sedangkan yang paling sedikit berada pada kegawat daruratan prioritas hijau dengan jumlah 38 responden $(38.0 \%)$.

Saat pasien datang di depan pintu IGD maka dicatat sebagai dimulaianya waktu tanggap tindakan keperawatan, setelah ditentukan diagnosa kerja dan kategori kegawatannya berdasarkan kategori triase, maka pencatatan dilanjutkan sesuai format yang ada. Untuk menghindari hilangnya data waktu yang overlaping maka dipakai penunjuk waktu dan pencatat waktu berupa jam dengan memakai Waktu Indonesia Bagian Tengah sebagai dasar perhitungannya. Observer melakukan pencatatan dengan mengikuti pasien mulai dari saat dilayani dan mencatat semua jenis tindakan keperawatan di IGD sesuai petunjuk pada format observasi dengan hasil observasi tindakan keperawatan menggunakan catatan waktu dalam hitungan menit.

Hasil penelitian ini sejalan dengan penelitian yang dilakukan oleh Apriani (2017), dimana dari 30 responden didapatkan 22 responden $(73,3 \%)$, yang termasuk kedalam prioritas 2,5 responden $(16,7 \%)$ yang termasuk kedalam prioritas 1 , dan 3 responden (10\%) yang termasuk dalan prioritas 3 pada pasien penderita jantung. Dimana untuk kecepatannya, 23 responden $(76,7 \%)$ mendapatkan waktu tanggap yang sangat cepat, sedangkan 7 responden $(23,3 \%)$ mendapatkan waktu tanggap cepat.

Berdasarkan hasil penelitian yang dilakukan rumah sakit Bhayangkara Kota Manado dengan sebagian besar kasus kegawat daruratan yaitu pasien dengan darurat tidak gawat. Kegawat daruratan pasien dapat mengalami perburukan kondisi atau akan semakin gawat hingga terjadi komplikasi dan kematian, apabila tidak ditangani dengan segera. Sangat penting dalam memprioritaskan kegawatan pasien sesuai dengan proses triase karena akan mempermudah untuk tindakan selanjutnya sesuai kebutuhan pasien.

\section{SIMPULAN}

Berdasarkan hasil analisa data dan pembahasan maka dapat disimpulkan sebagian besar pasien yang dating ke IGD berada pada umur Masa Lansia Awal 46 55 Tahun, sebagian besar Pasien yang dating ke IGD bedasarakan jenis kelamin laki-laki, dan Pasien yang dating ke Instalasi gawat darurat dengan kegawat daruratan Prioritas triase menunjukan sebagian besar Prioritas Triase kuning. Dengan demikian perlunya penambahan tenaga yang berkompeten yang memilki pelatihan-pelatihan dalam penanganan pasien kegawat daruratan.

\section{DAFTAR PUSTAKA}

Abidin, (2012). Makalah tentang perawat profesionalisme, diakses tanggal $25 \mathrm{Mei}$ 2017, http://www.masbid.com

Ade, 2018. Gambaran pelaksanaan code blue di ruang rawat inap dewasa rs. Dr. Wahidin sudiro husodoadesyamsuryadi. Jurnal

Apriani dan SyafitriFebriani, 2017. Hubungan Kegawat daruratan Dengan Waktu Tannggap Pada Pasien Jantung Koroner.Jurnal Kesehatan. Palembang

Aulia, 2019. Gambaran Response Time dan Lama Triage di Instalasi Gawat Darurat (IGD) Rumah Sakit Baladhika Husada Jember. Skripsi

Achmad, (2012). Faktor-Faktor Yang Berhubungan Dengan Lama Waktu Tanggap Perawat Pada Penanganan Asma Di Instalasi Gawat Darurat RSUD Panembahan Senopati Bantul, Jurnal Keperawatan Universitas Respati Yogyakarta, dalam http://ejournal.respati.ac.id. diakses 28 April 2017 Asri, 2017. Hubungan Pola Makan Dan Karakteristik Individu Terhadap Sindrom Dispepsia Pada Mahasiswa Angkatan 2015 Dan 2016 Fakultas Kedokteran Univeritas Hasanuddin, Skripsi 
Depkes. RI. (2011).Sistem Penanggulangan Gawat Darurat Terpadu. Jakarta: Departemen Kesehatan Republik Indonesia.

Dinkes DIY. (2013) Profil Kesehatan Istimewa Yogyakarta Tahun 2013. Dinas Kesehatan D.I. Yogyakarta, Yogyakarta.

Gray, D. (2012).Modul Pelatihan Pengembangan Manajemen kinerja klinik perawat/bidan. Jakarta.

Heru, S. 2015. Gambaran Pengetahuan Peran Perawat Dalam Ketepatan Waktu Tanggap Penanganan Kasus Gawat Darurat Di Instalasi Gawat Darurat Rumah Sakit Umum Daerah Karanganyar, Skripsi

Herkunanto, (2012). Penanggulangan Penderita Gawat Darurat Anestesiologi \& Reanimasi. Surabaya: FK. Unair.

Harbullah(2012)."Jenis dan metode pendidikan”.(Online).

(http://www.kajianpustaka.com/2012/11/je nis-dan-metode-pendidikan-dan.html).

Pada tanggal 27 Mei 2017.

Hadjam, (2013).Pengantar Keperawatan Profesional. EGC, Jakarta.

Hamurwono, (2012). Kertrampilan dalam Keperawatan Kamus Elektronik. Diakses tanggal 25 Mei 2017,

http://www.content.com. perawat dalam pelaksanaan penentuan prioritas penanganan kegawat daruratan jantung di igdrsud. Prof.dr. Ma. Hanafiah batu sangkar tahun 2019.jurnal

Keputusan Menteri Kesehatan Republik Indonesia. (2009). Standar Instalasi Gawat Darurat (IGD) Rumah Sakit. Jakarta: Menteri Kesehatan Republik Indonesia.

Kartikawati dan Musliha. (2014). Perbedaan waktu tanggap tindakan keperawatan di Instalasi Gawat Darurat RSUD Dr. Moewardi. Berita Ilmu Keperawatan.

Kusnanto, M, A. (2012). Pengantar Profesi dan Praktik keperawatan Profesional. Jakarta: EGC.

Maatilu V, (2014). Faktor-Faktor Yang Berhubungan Dengan Response Time Perawat Pada Penanganan Pasien Gawat Darurat Di IGD RSUP PROF.DR. R. D.
KANDOU MANADO,Jurnal Universitas Sumatera Barat,dalam http://ejournal.unsrat.ac.id. diakses 12 Maret 2017.

Mahyawati dan Widaryati, (2015). Hubungan Kegawat daruratan Pasien Dengan Waktu Tanggap Perawat Di IGD RS PKU Muhammadiyah Yogyakarta. Yogyakarta.

Nursalam. (2012). Manajemen Keperawatan, Aplikasi dalam Praktek Keperawatan Profesional. Jakarta:Salemba Medika..

Oman, Kathleen, S, McLain, Jane, Koziol, Scheetz, Linda, J, (2012). Keperawatan Emergenci. EGC. Jakarta

Potter, P. A dan Perry, A. G, (2012).Buku Ajar Fundamental Keperawatan: Konsep, Proses, dan Praktik, Jakarta: EGC.

Siswanto, (2013). Hubungan Beban dan Lama Kerja Dengan Waktu Tanggap Perawat Gawat Darurat Menurut Persepsi Pasien Di Instalasi Gawat Darurat RSU Pandan Arang Boyolali. Berita Ilmu Keperawatan ISSN 1979-2697, 1 (3), September 2013: 125-130, dalam http://publikasiilmiah.ums.ac.id diakses 18 April 2017

Siagian, (2011).pelatihan dalam Manajemen Sumber Daya Manusia Ed. 1, cet. 15. Jakarta: PT. Bumi Aksara

Surtiningsih, D., Susilo, C., dan Hamid, M. A. (2016). Penerapan Response Time Perawat Dalam Pelaksanaan Penentuan Prioritas Penanganan Kegawat daruratan Pada Pasien Kecelakaan Di IGD RSD Balung. The Indonesian Journal Of Health Science. 6(2): 124-131.

Sugiyono. (2018). Metode Penelitian Kuantitatif, Kualitatif, dan R\&D. Bandung: Alfabeta.

Susanti, V.(2018). Gambaran Pelaksanaan Triage Dan Respon Time Di Ruang Instalasi Gawat Darurat Rumah Sakit Islam Sultan Agung Semarang. Skripsi. Semarang: Fakultas Ilmu Keperawatan Universitas IslamSultan Agung.

Suryanti. (2019). Karakteristik penderita dispepsia pada kunjungan rawat jalan 
Jurnal Keperawatan, Volume 9, No. 1, Februari 2021, (Hal. 1-8)

praktek pribadi dr. Suryanti periode bulan oktober-desember 2018, Jurnal 